\title{
研究 会
}

\section{第 38 回 獣医麻酔研究会}

\author{
とき：1988年 9 月 25 日（日）午前 9 時 45 分〜个後 4 時 \\ ところ: 福島, 福島市ビューホテル
}

\section{[特別講演】}

\section{術後管理について}

赤間 洋 一

（福島県立医科大学麻酔科学教室）

手術や麻酔は生体にとって大きな侵襲であり, たと光手術・麻酔が終了してもこの侵襲から完全 に回復するとは限らない。このため術後には種々 の合併症を起こす危険がある。従って術後の患者 に打いては注意深い観察とより迅速な処置が必要 となる。以下術後管理の要点とその処置について 述べる。

1）意識状態の観察：麻酔からの覚醒状態, 各 種反射の有無, 応答, 四肢の反応, 意識レベ ルの推移などについて観察する。意識レベル の評価には通常 III-3-9度方式かグラスゴ ーコーマスケールが採用されている。術後不 隠・興奮状態が続く場合には低酸素血症, 高 炭酸ガス血症, ショック状態, 痛みなどが原 因していることもあり注意を要する。

2) 呼吸管理：術後には呼吸器系の合併症が高 率に発生し，これによる死亡率も高いので呼 吸管理は慎重かつ細心に行ら。術後に発生し やすい呼吸合併症としては気道閉塞, 呼吸運 動の抑制, 肺水腫, 無気肺, 肺感染症などあ げられる。これらの早期診断には呼吸状態の 臨床的観察, 胸部 $\mathrm{X}-\mathrm{P}$, 動脈血ガス分析, 酸素飽和度モニターなどが有用である。これ らの合併症に対し気道確保, 体位変換, ネプ ライザー, 酸素療法に加光必要に応じ人工呼 吸を行う。特に最近では人工呼吸のめざまし い進歩により重症呼吸不全患者でも救命でき るようになってきた。
3）術後管理：術後には呼吸系と同様に循環系 も不安定で, 血圧の変動な不整脈を発生しや すい状況にある。血圧，心拍数，心電図モ二 ター, 中心静脈圧などによる監視が必要であ る。また重症例ではスワン・ガンツカテーテ ルを用いた循環動態の把握が有用である。

4）体液・腎・尿量の管理：生体に侵襲が加わ ると体液は大きく変動し, 循環血液量が不足 してくる。従って，術中拈よび術後には十分 な輸液が必要となる。輸液不足の状態が長く 続くと酸塩基平衡障害や腎不全を合併してく るので尿量を時間ごとにモ二ターし腎不全の 予防に努めることが大切である。

5）代謝・栄養管理：術後にはエネルギー需要 が増大するが，耐糖能をはじめ種々の代謝異 常をきすため栄養系の利用能が低下する。特 に消化器系の手術患者では長期間食事摂取が できないため低栄養系の利用能が低下する。

この様な患者においては中心静脈栄養をは じめとした積極的な栄養管理が必要となる。

6）体温管理：術後の患者に扎いては種々の原 因により発熱をきたすことが多い。体温が $38^{\circ} \mathrm{C}$ 以上になると代謝の充進や水・電解質 の不均衡をきたすので原因のいかんを問わず 体温を下げる処置が必要となる。多くの症例 では水分の補給, 体部の冷却, 解熱剂の投与 などにより軽快するが，これでも体温上昇が 続く場合には発熱の原因を解明し適切な処置 をほどこさなければならない。

7）疼痛管理：疼痛は患者に多大な苦痛をあた えるばかりでなく，呼吸抑制や血圧上昇の原 因ともなる。従って患者の痛みを取除くこと 
は術後管理スムーズに行ら上で重要な意味を もつ。単に鎮痛薬の投与では不十分なことが 多く, 当教室では術後疼痛管理に持続硬膜外 神経ブロックを応用し良好な結果を得てい る。

その他, 手術術式や麻酔法などによって特殊な 観察や処置を必要とすることもあり, 術後管理に 扣いては麻酔科医と手術医との協力がきわめて重 要である。また，全身的合併症のある場合または その発生が予測される場合は ICU での管理が望 ましい。

\section{[一般講演 $]$}

\section{1. 犬の硬膜外麻酔の所見}

\section{特に追加投与による薬効と所見について}

森田馨, 直井昌之, 草場治雄,

佐藤 敬, 久保田泰一郎 (日本大学)

脊髄クモ膜下腔内一薬液を適用する脊椎麻醉 （一般に腰椎麻酔と呼ばれる）より，より安全性 が高いことから獣医界では脊䯣硬膜外腔内一適用 する硬膜外麻酔が利用され，尾椎麻酔と呼ばれて いる。

しかしながら, 小動物領域では, 安易な筋注, 静注薬の開発や吸入麻酔の普及など全身麻酔技術 が向上し，また硬膜外麻酔の技術上の欠点も加わ り，現在の利用度は極めて低い。私共は生体への 影響が少なく安全性の高い本法を犬に適用し，手 技と薬効について検討した。

術式は硫酸アトロピン，ジアゼパム，塩酸ケタ ミンにて麻酔へ導入させ, 硬膜外腔穿刺, 薬液 （リドカイン）注入を行った。注入にはカテーテ ルを留置し持続硬膜外麻醉を適用した。

結果 リドカイン $0.4 \mathrm{ml} / \mathrm{kg}$ を 2 分間で注入 した 1 群, $0.4 \mathrm{ml} / \mathrm{kg}$ を注入後その半量を 30 分 毎に 2 回追加注入した 2 群, 共に $\mathrm{T}_{11} \sim \mathrm{S}_{2}$ 脊䯣分 節の支配領域に無痛覚を示す例が認められ，1 群 では $60 \sim 90$ 分間， 2 群では約 2 時間の麻痺が得 られた。

脈拍数は投与前後の著変をみない。また心電図 上にも特異な所見をみなかった。呼吸数は投与時 減少する例が多かったが，その減少度はわずかで
あり，5分後は外界の刺激によると思われる増加 の例が多く認められた。血圧はいずれの例も，投 与中より下降したが，投与前の上昇からみると平 常に近ついたとも言光，この下降は 5 分後には再 び上昇しはじめた。

考察 硬膜外麻醉の麻痺範囲は薬の腔内での広 がりに左右されるが，この決定因子は穿刺部位と 薬液量が大いに関係する。私共は腰・仙椎間から 投与したが，カテーテルを用い上位の腰椎へ注入 することも行ったが，前記注入量では呼吸筋の麻 痺などの所見を経験しなかった。特に発生頻度の 高い血圧下降の所見もみなかったことから，本法 に細かい手技の検討を加光，実用性への確立を考 えたい。

\section{2. 犬の脊髄損傷症例に対するイオヘキソールに よる脊髄造影と麻酔について}

南 毅生，渡辺俊文，石川義広， 武藤 真, 若尾義人, 鈴木立雄, 高橋 貢

(麻布大学獣医学部外科)

椎体骨折を治療する場合，脊髄圧迫の度合いを 観察する目的で脊髄造影が実施される。しかしな がら，しばしば脊髄造影後に，てんかんやけいれ んが発生するため，それらを軽減する目的で種々 の造影剂が開発されている。最近, 非イオン性の 新しい造影剂が開発され, 従来からの造影剂と比 較して，てんかんやけいれんの発生率がかなり低 下すると報告されている。また，一方では造影後 のてんかんやけいれんの発生を予防するため， ： ルビタール麻酔や輸液剂による利尿などが試みら れてきた。

今回，4例の胸椎損傷犬に対して非イオン性の 新しい造影剂であるイオへキソール（オムニパー ク 240）を使用し，現在我々がルーチンに行って いる麻酔導入法と八ロセンによる維持麻酔で脊䯣 造影と整復手術を実施したところ，術後，何ら異 常な神経症状が認められなかったのでとの概要を 報告する。

症例は，表 1 に示したとおりシェットランド・ シープドック，ポメラニアン，ドーベルマン，雑 
表 1 症例一覧

\begin{tabular}{|c|c|c|c|c|}
\hline 症例番号 & 犬 & 性 別 & 年齢 (歳) & 体重 $(\mathrm{kg})$ \\
\hline 1 & シェットランド・シープドッグ & $\hat{\delta}$ & 2 & 4.5 \\
\hline 2 & ポメラニアン & 우 & 2 & 1.85 \\
\hline 3 & 雑 & 令 & 0.5 & 5.4 \\
\hline 4 & ドーベルマン & $q$ & 1 & 25.0 \\
\hline
\end{tabular}

表 2 導入麻酔剂と維持麻酔剂

\begin{tabular}{|c|c|c|c|}
\hline 症例番号 & 導 & 麻 & 維 持 麻 酔 剂 \\
\hline 1 & $\begin{array}{l}\text { フルニトラゼパム } \\
\text { 塩酸ケタミシ }\end{array}$ & $\begin{array}{l}0.1 \mathrm{mg} / \mathrm{kg} \\
3 \mathrm{mg} / \mathrm{kg}\end{array}$ & フローセン \\
\hline 2 & $\begin{array}{l}\text { フルニトラゼパム } \\
\text { 塩酸ケタミン }\end{array}$ & $\begin{array}{l}0.1 \mathrm{mg} / \mathrm{kg} \\
3 \mathrm{mg} / \mathrm{kg}\end{array}$ & フローセン \\
\hline 3 & $\begin{array}{l}\text { ジアゼパム } \\
\text { 塩酸ケタミン }\end{array}$ & $\begin{array}{l}0,1 \mathrm{mg} / \mathrm{kg} \\
5 \mathrm{mg} / \mathrm{kg}\end{array}$ & フローセン \\
\hline 4 & $\begin{array}{l}\text { フルニトラゼパム } \\
\text { 塩酸ケタミン }\end{array}$ & $\begin{array}{l}0.08 \mathrm{mg} / \mathrm{kg} \\
4 \mathrm{mg} / \mathrm{kg}\end{array}$ & フローセン \\
\hline
\end{tabular}

表 3 麻酔時間と各時間間隔

\begin{tabular}{|c|c|c|c|}
\hline 症例番号 & $\begin{array}{l}\text { 麻酔時間 } \\
\text { (分) }\end{array}$ & $\begin{array}{l}\text { 麻酔導入から脊骵造影ま } \\
\text { での時間 (分) }\end{array}$ & $\begin{array}{l}\text { 春髄造影から麻酔終了ま } \\
\text { での時間 (分) }\end{array}$ \\
\hline 1 & 168 & 136 & 32 \\
\hline 2 & 172 & 46 & 126 \\
\hline 3 & 163 & 22 & 141 \\
\hline 4 & 225 & 13 & 212 \\
\hline
\end{tabular}

表 4 診断名と手術方法

\begin{tabular}{|c|c|c|c|}
\hline 症例番号 & 診断 名 & 術 & 法 \\
\hline 1 & 第 12,13 胸椎間の脱臼 & $\begin{array}{l}\text { 第 } 12,13 \text { 胸椎の椎弓切除術 } \\
\text { プレートによる固定 }\end{array}$ & \\
\hline 2 & 第11胸椎の骨折 & $\begin{array}{l}\text { 第 } 10,11 \text { 胸椎の半椎弓切除術 } \\
\text { プレートによる固定 }\end{array}$ & \\
\hline 3 & 第11胸椎の骨折 & $\begin{array}{l}\text { 第10,11胸椎の椎弓切除術 } \\
\text { プレートによる固定 }\end{array}$ & \\
\hline 4 & 第11胸椎の骨折 & $\begin{array}{l}10,11 \text { 胸椎の椎弓切除術 } \\
9,12 \text { 胸椎の半椎弓切除術 } \\
\text { プレートによる固定 }\end{array}$ & \\
\hline
\end{tabular}

種の各 1 例で，体重は，1.85 25.0 kg であった。

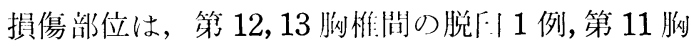
椎の骨折 3 例であった。
林酔方法は，まず硫酸アトロピンを $0.025 \mathrm{mg} /$ $\mathrm{kg}$ の用量で斗下注射し，15 分後に $100 \%$ 酸素を マスク法にて 5 分間吸入させた後, 表 2 に示した 
用量でフルニトラゼパムまたはジアゼパムと塩酸 ケタミンを混合し，one shot で静脈内に投与し 喉頭反射が消失後気管挿管を行った。維持麻酔に は八ロセンを使用し, 麻酔中は心拍数, 心電図, 血圧，体温を監視して麻酔深度を第 3 期 $1 \sim 3$ 相 で維持した。

奉髄造影法は，麻酔が安定した後，大槽より $22 \mathrm{G}$ の静脈針で硬膜下を穿刺し，脊䯣液を 0.3 $\mathrm{ml} / \mathrm{kg}$ の用量で採取後, 同量のオムニパークを 同部位から注入した。その後, 体位を約 45 度に 頭塑を上方に傾けた状態で 5 分毎に造影剤が損傷 部に到達しその部分の圧迫の度合いが明確になる までX線撮影を行った。

麻酔時間は 163〜225 分で，麻酔導入から分能道 造影までの時間は，13〜136 分であった。また， 脊髄造影より麻酔(手術)終了までの時間は，32〜 212 分であった(表 3)。1 例においては, 脊髄損 傷が重度なため術後に䧳髄造影を行った。手術方 法は表 4 のと打りである。

一般に脊髄造影から麻酔終了までの時間が短い 場合，てんかんの発生率が高くなるという報告が あるものの，体重の異なるイスに対してハロセン 麻酔下にオムニパークを用いて徐䯣造影を実施し たところ，症例数は少ないがてんかんやけいれん を認めた例はなく，オムニパークは副作用の発生 率の少ない造影剤と思われた。今後は, 症例数を 増やすと共にオムニパークの注入量とてんかんや けいれんの発生率ならびに撮影状態等について追 求して行きたい。

\section{3. イヌにおける新しい吸入麻酔薬の比較 一特に虚血心筋犬に対して一}

木村 準 ${ }^{1)}$ ，星 理恵 ${ }^{1)}$ ，星 源孝1)， 谷藤泰正 ${ }^{2}$, 堀口 徹 ${ }^{2)}$, 影嶋和幸 ${ }^{2)}$, 安田信彦2), 小林健一 ${ }^{2)}$, 安江俊二 ${ }^{32}$, 小宮山典寛 ${ }^{4)}$

(1)日本文化厚生財団成人病医研,

2) 東京綕恵会医科大森酔科,

3) 福島県立会津短大,

4)三鷹獣医科グルーブ)

獣医臨床では，各種の症例に対して種々の麻醉
法が，限られたスタッフ，設備等の条件内で臨床 応用されているが，必ずしも理想的な麻酔を充分 に垁施できる現状ではない。

そこで，今回我々は将来，獣医臨床特に循環障 害の症例に応用する目的で，実験的に虚血心筋犬 を作成し，人医界で新しく開発された吸入麻醉薬 で，速やかな導入と覚醒が期待されるセボフルレ ン及びイソフルレン（血液/ガス溶解係数がそれ ぞれ 0.59 と 1.40）と，吸入麻醉薬として使用頻 度が高いハロセンの各吸入麻醉を行い，さらに疼 痛刺激を加え心筋酸素需給平衡を観察し，新しい 吸入麻酔薬の検討を行った。

実験には，諸検査の結果，健康と認められた雑 種成犬 6 頭を使用し，麻酔導入はマスクにより， イソフルレン，セボフルレンまたは八ロセンのい ずれか一種類と酸素のみにより行った。呼吸は, 人工呼吸器により臭化パンクロニウム下で, $\mathrm{PaCO}_{2} 35 \pm 5 \mathrm{mmHg}$ にコントロールした。そこ で, Swan-ganz カテーテルを頸静脈より肺動脈 へ，カットダウンチューブを股動脈へ挿入した。 そして，左第 4 ，第 5 肋間を開胸し，左冠動脈回 旋技起始部に超音波トランジット血流計を装着 し，股静脈よりソーンズカテーテルを冠静脈洞へ 留置し，心拍数・ 心拍出量・冠動脈血流量 - 平均 体動脈圧・心管酸素消費量等を測定・算出した。 さらに，左冠動脈前下行枝第 2 分枝部を結禁後 2 時間放置し，虚血心筋流が安定したところで，各 吸入麻酔の $1 \mathrm{M}$.A.C. 麻酔濃度を 60 分間吸入乙 た。そして，疼痛刺激として 1 分間の tail clamp を行い，刺激負荷の前後に执いて諸量の測定を実 施し，疼痛刺激による影響を観察した。

なお，実験中は胸腹部をプラスチックシートで 被覆し, さらに加温・加湿を行い, 特に臓器温度 の低下括よび蔵器表面の乾燥を防止した。

その結果，特に虚血心筋犬に対する，イソフル レン，セボフルレン，及びハロセンの 1 M.A.C. 吸入麻酔に拈ける比較では，イソフルレンの循環 抑制が最も少ないことが観察され，虚血心筋の上 らな病態の循環障害を伴う症例では，イソフルレ ンが最も適当な吸入麻酔薬であることが示㖫され た。 
4. マウスの簡易吸入麻酔における塩酸イソクス プリンとエーテルの併用

井上吉浩 ${ }^{12}$, 加藤 清 $^{2}$, 大和田一雄 ${ }^{12}$, 信永利馬 ${ }^{3}$,

(1)山形大・医・動物実験， ${ }^{4)}$ ・イセイ， 3) 東北大・医・動物実験）

巅者らは実験小動物に汎用される簡便かつ安全 なェーテル麻酔の条件と, その時得られる麻酔持 続時間について検討し既に報告した。今回はエー テルと神経系を介さず平滑筋弛緩作用を示す塩酸 イソクスプリンの併用効果について検討したので 報告する。

動物：ICR マウスの雄, $5 \sim 7$ 週秢。

試薬：エチルェーテルは試薬特級, イソクスプ リンはズファジラン(浅)(第一製薬)。

麻酔の導入は, 麻酔ジャーとして $500 \mathrm{ml}$ のビ 一カーを用い, $5 \mathrm{~g}$ の脱脂綿に $10 \mathrm{ml}$ のエーテル をしみこませ，その上を金網で覆い，直接動物と エーテルが接しないようにし，蓋にはガラス製の シャーレを用いた。塩酸イソクスプリンとしてそ れぞれ $2 \mathrm{mg} / \mathrm{kg}, 10 \mathrm{mg} / \mathrm{kg}, 50 \mathrm{mg} / \mathrm{kg}$ を頸背部 に皮下注射し, その 5 分及び 10 分後に動物を麻 醉ジャ一の中に入れ, 各々 60 秒， 90 秒， 120 秒 間エーテルに曝露した。維持麻酔は, 麻酔ジャ一 による 60 秒間の導入麻酔ののち, 維持麻酔用に 作製したプラスチック製のカップに $0.5 \mathrm{~g}$ の脱脂 綿をつめ,これに $0.1 \mathrm{ml}$ のエーテルをしみこま せたものをかぶせることにより行った。また，麻 酔ジャ一へのエーテルの添加量を隇じた場合の導 入及び維持麻酔についても検討した。エーテル麻 酔については，動物の生死及び麻酔持続時間を観 察した。麻酔持続時間は, ジャ一から取り出した 動物を実験台上に背位に置いてから（維持麻酔で はカップをかぶせてから), 最初に起き上がるま での時間とした。エーテル及び脱脂綿は 1 匹毎に 新しいものと交換した。な打対照としては生理食 塩液を注射した。

1. 導入麻醉において, 死亡する動物の割合 は，対照群とイソクスプリン投与群との間に 特に差はみられないが，イソクスプリン注射 後 5 分でェーテルに 60 秒間樭露した群では,
$2 \mathrm{mg} / \mathrm{kg}, 10 \mathrm{mg} / \mathrm{kg}$ 群とも死亡例はなかっ たが，麻酔持続時間は対照群 (平均 37 秒) に 比べて長く, $2 \mathrm{mg} / \mathrm{kg}$ 群で約 2 倍（平均 77 秒), $10 \mathrm{mg} / \mathrm{kg}$ 群で約 3 倍 (平均 102 秒) の 持続時間が得られた。

2. 維持麻醉を行った時の麻醉持続時間は, 対 照群 (平均 3 分 59 秒) に対して, $2 \mathrm{mg} / \mathrm{kg}$ 群 (平均 9 分 39 秒), $10 \mathrm{mg} / \mathrm{kg}$ 群 (平均 8 分 47 秒) と約 2 倍の持続時間が得られた。

3. 麻酔ジャーへのエーテルの添加量を $5 \mathrm{ml}$ に減じると対照群では麻酔効果が得られない 個体があったのに対し，イソクスプリン 10 $\mathrm{mg} / \mathrm{kg}$ 群では全例麻酔効果が得られ，麻酔 持続時間も延長した。

\section{5. 猫のキシラジン，ケタミン併用麻酔に対す るトラゾリン, ヨヒンビンの拮抗効果の比 較}

鈴木克已，窪田正昭，中村忠司， 日篎喜朗, 高瀬勝晤, 角田知子, 小笠原成郎（北里大）

近年, $\alpha_{2}$ 遮断薬の $ヨ$ ヒビン $(\mathrm{Yo})$, トラゾリ ン（To）がキラシラジン（Xy）の諸作用に括抗 することが明らかにされ, Yoと ToはXyを併 用した麻酔に対する拮抗薬としても使用できると の報告が数多くなされてきた。猫のキシラジン， ケタミン (Ket) 併用麻酔に対してはYo 単独あ るいは Yo+4Ap が拮抗効果を示すことが報告さ れている。今回，猫に打ける Xy, Ket 併用麻酔 の怙抗薬として Yo と To を臨床応用する目的 で，その投与量について，一般臨床所見から比較 検討したので報告する。

雑種成猫 10 頭を用い，実験 1) ではYo の效 果について, 実験 2) ではTo 効果について調べ た。いずれの実験も全群に硫酸アトロピン 0.05 $\mathrm{mg} / \mathrm{kg}$ 皮下注し, 15 分後 Xy $2 \mathrm{mg} / \mathrm{kg}$ 筋注し, さらに 15 分後 Ket $15 \mathrm{mg} / \mathrm{kg}$ を筋注した。Ket 投与後, 実験 1）では対照群に生食液, Yo 群に $0.1 ， 0.2 ， 0.4,0.8 \mathrm{mg} / \mathrm{kg}$ を静注し，実験 2) では, 対照群に生食液, To 群に To $1,2,4$, $8 \mathrm{mg} / \mathrm{kg}$ を静注した。 
その結果，実験 1) では，Yo 投与群はいずれ の群も対照群に比へ麻酔からの覚醒が早まり, そ の効果は Yo 投与量に依存した。また，対照群で 又られた体温下降, 徐脈, 呼吸数の減少について も Yo 投与量の多い群皃どそれらの回復が早まっ た。しかし，Yo 投与量の多い群ほど筋の拘縮が 強く認められた。Yo $0.1 \sim 0.2 \mathrm{mg} / \mathrm{kg}$ 投与群に はその他特に副作用はみられなかったが，Yo $0.4 \sim 0.8 \mathrm{mg} / \mathrm{kg}$ 投与群には Yo 投与後著しい頻 拍, 呼吸促拍がみられ, 明らかな不安, 過敏症状 も認められた。

実験 2）では，実験 1）のYo と同様に To 投 与量の多い群ほど対照群に比べ麻酔から覚醒が早 まり，その効果は Yo 0.1 0.2 mg/ $\mathrm{kg}$ に対し To $2 \sim 4 \mathrm{mg} / \mathrm{kg}$ が同程度であった。また，To 投与 量の多い群ほど Xy·Ket 麻酔後の体温下降, 徐 脈, 呼吸数の減少は抑えられたが，逆に筋の拘 縮, 可視粘膜の充血, 頸背部の立毛が To 投与量 の多い群ほど強く認められた。To $1 \sim 4 \mathrm{mg} / \mathrm{kg}$ 投与群にはその他特に副作用は認められなかった が, To $8 \mathrm{mg} / \mathrm{kg}$ には頻拍, 呼吸促拍がみられ た。しかし，Yo 投与群でみられた様な著しい不 安，過敨症状は To 投与群で認めら机なかった。

以上のよらに, Yo と Toは共に猫の Xy·Ket 併用麻酔に対し明らかな拮抗効果を示し, 臨床上 で拮抗薬として用いる場合, 副作用の程度から Yo $0.1 \sim 0.2 \mathrm{mg} / \mathrm{kg}$, To $1 \sim 4 \mathrm{mg} / \mathrm{kg}$ の静注:が 適量之思われる。また，これらの投与量では副作 用のより少ないYoの方が優れていると思われる が，Yo の過剩投与には十分注意を要すると考光 ら机る。

\section{6. 犬の全身麻酔および開胸手術における経皮ガ スモニターの臨床的検討}

原 茂雄, 生田健太郎, 料地誉利子, 沢田晴之, 福田稔彦, 藤井義雄, 菅野 弘（岩手大）

全身麻酔における術前から術後覚醒に至るまで のモニターには種々な医用エレクトロニクス器械 が使用されている。それらの中でも血液ガスを逨 続的あるいは経時的, 非侵襲的にモニターするこ
とは困難であった。経皮ガスモニタ一装置は, 動 脈血ガス分析法にとって代わるものではないが， 経皮的な酸素 $\left(\mathrm{tcPO}_{2}\right)$ 和よび炭酸ガス $(\mathrm{tcPCO})$ の測定は血液動態の変化を反映するものとして人 では新生児から成人患者に使用されるようになっ た。今回, 犬の全身麻酔と手術に用いた場合の成 績について検討したのでその概要を報告する。

材料と方法 実験動物として雑種成犬 6 頭（体 重 9-12 kg）を用いた。供試犬は全例とも24 時 間絶食させ，硫酸アトロピン $(0.03 \mathrm{mg} / \mathrm{kg}, \mathrm{s.c}$. 投与後，次の如き麻酔と手術を行なった。

1. チオペンタールナトリウム $(20 \mathrm{mg} / \mathrm{kg}$, i.v.) 投与後気管挿管し，フローセン吸入麻

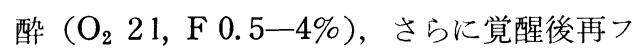
ローセン吸入麻酔,

2. プロピオニール プロマジン $(0.03 \mathrm{mg} /$ $\mathrm{kg}$, i.m.) 投与後, チオペンタール $(20 \mathrm{mg} /$ $\mathrm{kg}$, i.v.)，氛管挿管後フローセン吸入麻酔 $\left(\mathrm{O}_{2} 21, \mathrm{~F} 0.5-4 \%\right)$,

3. 前述 1）の麻酔下で開胸し, 右心室穿刺術 を行なった。

経皮ガスモニタ一装置として住友電工製経皮 $\mathrm{O}_{2} / \mathrm{CO}_{2}$ モニタ（PO-550）を用いた。電極の温度 は $43.5^{\circ} \mathrm{C}$ として, 腹壁あるいは大腿部（内側） を剃毛し，麻酔前から覚醒に至るまで接着固定さ せた。その交脈博数, 心電図, 休温, 呼吸数につ いてもモニターした。

結果 1 . 硫酸アトロピン拈よびチオペンター ルによる影響は認められなかった。

2. フローセン吸入麻酔にともない $\mathrm{tcPO}_{2}$ は高值を示したが，麻酔停止に より速やかに回復した。 $\mathrm{tcPO}_{2}$ には著 変は認められなかった。しかし, 再び 吸入麻酔に入ると $\mathrm{tcPO}_{2}$ は低值を示 し， $\mathrm{tcPO}_{2}$ は序々に上昇した。

3. フローセン吸入麻酔前にプロピオニ ールプロマジンを投与した場合は, 前 述 2 のような変化は認められず, $\mathrm{tcPO}_{2}$ および $\mathrm{tcPO}_{2}$ に著変は認めな かなかった。

4. フローセン吸入麻酔下の開胸手術に 
おいては，麻酔については激述 2 と同 椂な変化であったが，開栃・調節呼吸 之ともに $\mathrm{tcPO}_{2}$ は低值を示し，バッ クの加圧に応じて変化した。一五, $\mathrm{tcPO}_{2}$ は逝に序々に上昇した。

以上の絡果から経皮ガスモニタ一は糜酤剂，麻

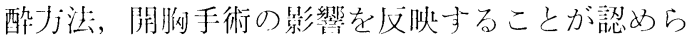

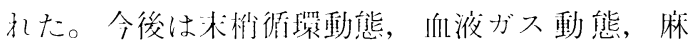
酔・手術などの相互関係について比較检討を裂す るものと思われる。

\section{7. 犬の腎膿瘍摘出手術時の麻酔および手術管理 の 1 例}

多川政弘，汇帛博康（日獣大）

婜脿湯は，1:行性の㽷路感染または血行性の細 凩感染から起こる。类た，ての多くは，水腎症， 婜絬石，外傷による腎蔵血腫などに継発する。腎

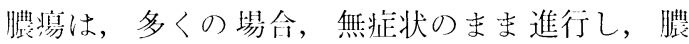

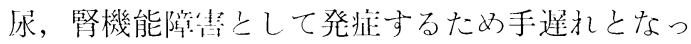
て患側腎の摘出を余儀なくさ机ることがしばしば ある。今回演者らは，高空素血症を呈した腎膿瘍 の大について牌摘出手術を行なったので，その 僺酔および手術経過について報告する。

[症例]

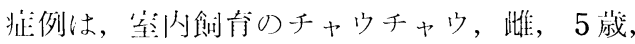
体重 $21.8 \mathrm{~kg}$ である。1 週䦌程解また食欲の低下

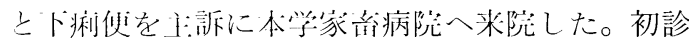
時の検查所胃は，体滥 $37.9^{\circ} \mathrm{C}$ で肺野に粗机い当 を認めた。血液検查は，RBC 788 \%，Ht $43 \%$, Hb $12.6 \mathrm{~g} / \mathrm{dl}$, WBC 27200, TP $7.7 \mathrm{~g} / \mathrm{dl}$, GOT 55KU, GPT 22KU, ALP 339KAU, BUN 55. 6 $\mathrm{mg} / \mathrm{dl}, \mathrm{Cr} 3.8 \mathrm{mg} / \mathrm{dl}$ であった。X線所見は， = ギリコブシ大に腫大した左腎を認め，エコー所見 で腎孟の掘大と腎笑質の肥厚を認妉た。尿検查の ために算尿したところ膿尿を確認した。以上の結 果から腎膿㿇を疑い開腹手術を実施した。

〔麻酔一法之手術経過]

麻酔方法は，まずアトロピン $0.05 \mathrm{mg} / \mathrm{kg}$ とべ ロペリドール $0.5 \mathrm{mg} / \mathrm{kg}$ を筋注して鎮静させた のセ血管を確保してデキサメサン゙ン $1 \mathrm{mg} / \mathrm{kg} を$ 静注した。つぎにケタミン $5 \mathrm{mg} / \mathrm{kg}$ を静泣しし,
GOF $\left(\mathrm{O}_{2}: \mathrm{N}_{2}=1: 1\right.$, 八ロセン $\left.1 \sim 2.5 \%\right)$ 麻酔 で尊入・維持した。また，術中は乳酸版りン゙ル $20 \mathrm{ml} / \mathrm{kg} / \mathrm{hr}$ ．を輸液して腎血流量を維持した。

手術は，両側腎を確認するため正中切開に上る アプローチで開腹した。左腎は，挙大に腫大し， 被膜下出血，軟化を認めたため型のごとく摘出し た。麻酔 167 川多間分，手術時閒 108 分，覚醒時間 56 分であった。摘出した左腎は，腎孟に膿汁が 眝留し，笑質内にも膿瘍を認めた。

「術後の経過】

膿汁の細菌検查から E. coli を検出し，感受性 ディスクの結果，腎毒性など副作用が少なく，抗 菌スペクトルの広、第 3 世代セフェム系のセフタ ジジム (モダシン) $125 \mathrm{mg} /$ head を 1 日 2 [问静脈 内投与した。また，フロセミド $40 \mathrm{mg} /$ day を投 与し利尿させた。術後の経過は比較的良好で， 2 日目から普通食を食べた。術後 3 日目にBUN $90.8 \mathrm{mg} / \mathrm{dl}, \mathrm{Cr} 5.7 \mathrm{mg} / \mathrm{dl}$ まで上昇したが以後漸 減し，10 日目の退院時には BUN $60.5 \mathrm{mg} / \mathrm{dl}$ で, 1 力月目の検査では，普通食にもかかわらず BUN $68.1 \mathrm{mg} / \mathrm{dl}, \mathrm{Cr} 2.4 \mathrm{mg} / \mathrm{dl}$ で一般状態は改 善された。

\section{8. 心エコー法による左心機能と麻酔との検討特 に鎮静時と深麻酔時の左心機能の比較}

久保田英治，加藤周子，吉野 絮 (仙台市開業)

犬の心機能検查は，一般的に心カテーテル法に よって行われて扣り，ての評価も高い。しかしな がら，重篤な症例への応用，あるいは反復検査な どの点を考虑すると，垁際の臨床の皆では，おの ずと制約されることは少なくない。これに相対し て超音波画像部断装置による心機能検査は，非観 血的で容易に笑施され，重篤な症例にも反復検査 が可能であり，検查による侵襲も少なく，乙か も，装置の計算機能によってリアルタイムに計算 数值が表示されるなど多くの利点がある。

今回，演者らは，心エコー法を応用し，健康犬 群と，被手術犬群などの 2 群の各症例に施した鎮 静時と，麻酔時の左心機能検査を試及た。

供試犬：臨床的に健康と思われる 2 例と，父 
管虚脱，朋蔵癌，のら胞腎，子宮蓄 膿症, 膀胼腫瘍, セルトリ細胞腫, 膝蓋骨脱田など各々 1 例で計10例を 対象とした。年齢は 5 歳から16撜で あり, 体重は $2.7 \mathrm{~kg} \sim 22.7 \mathrm{~kg}$ であ った。

検查機器: TOSHIBA 複合走查形超音波画像 誩断装置 SAL-38B を使用した。

才 法: 左心機能の測定は, 硫酸アトロピン $0.03 \mathrm{mg} / \mathrm{kg}$, ドロペリドール 0.25 $\mathrm{mg} / \mathrm{kg}$ 投与後の鎮静時と, フロー 七ン麻䣫下の深麻酔時とおいて測定 した。測定方法は，あらかじめ B モ ードで超音波ビーム方向を確認して からMモードを表示し，僧帽弁前尖 の見觉かくれする位置で，抆張期と 収縮期の左室短待を計測し, 装置の 計算機能によって, 左室拡張末期量 (EDV)，左室収縮末期量（ESV）, 左室 1 回拍出量 (SV), 心拍出量
( $\mathrm{CO} /$ 分）駆出率（EF）などの 5 項 目について計算した。計算方法は, 装置にあらかじめセットしたCUBE (POMBO 法)に従った。 績：健康犬群，被手術犬群ともに，鎮静 時に比較して深麻醉時の左心機能低 下が認められた。すなわち，健康犬 群では SV 29.45\%, CO 45.58\%, EF 11.26\% の低下がみられた。ま た被手術犬ではで，それぞれの検查 項目に扮いて数值の低下がみられ た。

考察：心ェコー法を応用して, 健康犬群と 被手術犬群の鎮静時と深麻酔時の左 心機能を検査した。とくに被手術犬 の中での高い注ど左心機能の低下が 及られたことから, 容易に検査可能 な本法の応用は, 手術計画, 術中の 病態観察, 術後管理に際し, 有用性 の高いものと考えられた。 